\title{
Nadciśnienie u młodych dorosłych męizczyzn — jak je optymalnie leczyć?
}

\author{
Krystyna Widecka
}

Klinika Hipertensjologii i Chorób Wewnętrznych Pomorskiego Uniwersytetu Medycznego w Szczecinie

\section{Streszczenie}

Nadciśnienie tętnicze jest chorobą cywilizacyjną, której częstość rośnie wraz z wiekiem. W ostatnich latach obserwuje się coraz większe rozpowszechnienie nadciśnienia samoistnego wśród młodych dorosłych.

Nadciśnienie tętnicze u młodych chorych jest zaburzeniem hemodynamicznym, które we wczesnej fazie charakteryzuje się dużą pojemnością wyrzutową i prawidłowym oporem obwodowym, natomiast w bardziej utrwalonej fazie choroby obserwuje się prawidłową lub zmniejszoną pojemność minutową oraz zwiększony całkowity opór obwodowy.

W postępowaniu diagnostycznym istotne znaczenie mają badania laboratoryjne, ponieważ umożliwiają ocenę ryzyka sercowo-naczyniowego, powikłań narządowych oraz rozpoznanie wtórnych postaci nadciśnienia tętniczego.

Z uwagi na brak dużych wieloośrodkowych badań klinicznych decyzja o leczeniu farmakologicznym młodych chorych podejmowana jest głównie na podstawie opinii ekspertów i doświadczeń własnych.

Należy mieć świadomość, że celem krótkoterminowym u takich pacjentów nie jest zapobieganie incydentom sercowo-naczyniowym i zgonom z ich powodu, ponieważ są one mało prawdopodobne. Właściwym celem leczenia hipotensyjnego u młodych chorych powinno być zapobieganie postępowi nadciśnienia tętniczego i wystąpieniu lub progresji subklinicznych uszkodzeń narządowych, które ostatecznie prowadzą do jawnej choroby sercowo-naczyniowej i śmierci.

Przeprowadzone metaanalizy jednoznacznie wskazują, że skuteczne obniżenie ciśnienia tętniczego nie może być jedynym celem terapii. Leczenie hipotensyjne powinno poprawić jakość życia, wywierać korzystny wpływ na zaburzenia hemodynamiczne, metaboliczne i prowadzić do regresji wtórnych do nadciśnienia zmian narządowych, co w przyszłości spowoduje zmniejszenie chorobowości i śmiertelności w tej grupie chorych.

słowa kluczowe: nadciśnienie samoistne, młodzi dorośli, mężczyźni, leczenie, perindopril

Arterial Hypertens. 2016, vol. 20, no. 3, pages: 89-101

DOI: $10.5603 / A H .2016 .0014$

\section{Epidemiologia}

Nadciśnienie tętnicze (AH, arterial hypertension) jest chorobą cywilizacyjną, której częstość rośnie wraz $\mathrm{z}$ wiekiem $[1,2]$. W ostatnich latach obserwuje się coraz większe rozpowszechnienie nadciśnienia samoistnego wśród osób dorosłych w młodym wieku.

\footnotetext{
Adres do korespondencji: prof. dr hab. n. med. Krystyna Widecka Klinika Hipertensjologii i Chorób Wewnętrznych, Pomorski Uniwersytet Medyczny

ul. Unii Lubelskiej 1, 71-252 Szczecin

e-mail: widecka@02.pl
}

V M Copyright (c) 2016 Via Medica, ISSN 2449-6170
Badania epidemiologiczne, przeprowadzone w Europie i w Stanach Zjednoczonych, w grupie wiekowej 35-44 lata wykazały, że częstość AH w tej populacji jest większa w Europie (27\%) niż w USA (14\%) [3]. Stwierdzono, że grupę młodych dorosłych charakteryzuje najbardziej wyrażone względne zwiększenie (nawet o 41\%) częstości występowania tej choroby [4]. W polskim badaniu epidemiologicznym o akronimie NATPOL III PLUS (Nadciśnienie Tętnicze w Polsce Plus Zaburzenia Lipidowe i Cukrzyca) wyodrębniono populację osób w wieku 18-39 lat. Częstość nadciśnienia w tej grupie wiekowej była istotnie większa u mężczyzn (11\%) w porównaniu z kobietami $(3,4 \%)$ [5]. W innym polskim badaniu epidemiologicznym, 
o akronimie WOBASZ (Wieloośrodkowe Ogólnopolskie Badanie Stanu Zdrowia Ludności), w grupie wiekowej 20-34 lata częstość nadciśnienia u kobiet wynosiła $2 \%$, a u mężczyzn - $15 \%$, natomiast w grupie wiekowej 35-44 lata u kobiet — 9\%, a u mężczyzn $-25 \%[6]$.

\section{Odrębności patofizjologiczne}

\section{Hemodynamika ciśnienia tętniczego}

Nadciśnienie tętnicze u młodych chorych jest zaburzeniem hemodynamicznym, które we wczesnej fazie charakteryzuje się dużą pojemnością wyrzutową i prawidłowym oporem obwodowym, natomiast w bardziej utrwalonej fazie choroby obserwuje się prawidłową lub zmniejszoną pojemność minutową (CO, cardiac output) oraz zwiększony całkowity opór obwodowy (TPR, total peripherial resistance). W AH wczesnym objawem zaburzeń czynności serca jest zmiana objętości wyrzutowej (SV, stroke volume), zwłaszcza w czasie wysiłku fizycznego.

Wyniki wielu badań wykazują, że u większości młodych pacjentów z AH występuje krążenie hiperkinetyczne, wyrażone zwiększoną częstotliwością rytmu serca ( $\mathrm{HR}$, heart rate) i zwiększonym rzutem serca oraz zwiększonym przepływem krwi w obrębie przedramienia $[7,8]$.

Powszechnie przyjmuje się, że ważniejszym czynnikiem ryzyka sercowo-naczyniowego u osób przed 50. rokiem życia jest wartość ciśnienia rozkurczowego (DBP, diastolic blood pressure), podczas gdy u osób po 50. roku życia - wartość ciśnienia skurczowego (SBP, systolic blood pressure) [9].

Wartość DBP u młodych pacjentów zależy głównie od TPR i dlatego niskie DBP wskazuje na niski opór obwodowy. Ponadto u młodszych pacjentów z krązeniem hiperkinetycznym DBP jest bardziej stabilne niż SBP i lepiej odzwierciedla ryzyko sercowo-naczyniowe [10-13]. U osób starszych niskie DBP wynika z dużej sztywności naczyń tętniczych, która jest przejawem bardziej procesu starzenia się tętnic niż niskiego TPR $[1,2]$.

\section{Izolowane nadciśnienie rozkurczowe}

Najczęstszą postacią nadciśnienia u młodych jest izolowane nadciśnienie rozkurczowe (IDH, isolated diastolic hypertension). W ostatnio opublikowanym piśmiennictwie sugeruje się, że hemodynamika IDH jest niejednorodna. Wykazano istnienie odmiennych fenotypów hemodynamicznych u młodych chorych z IDH. Z jednej strony potwierdzono już wcześniej publikowane informacje, że większość młodych z IDH wykazuje tzw. fenotyp wazotoniczny, co oznacza niski $\mathrm{CO}$ z wysokim TPR, ale z drugiej strony ujawniono mniej znane mechanizmy rozwoju IDH dotyczące „fenotypu hiperkinetycznego" zależnego od zwiększonej SV serca $[14,15]$. U 37\% osób z kohorty młodych pacjentów z nadciśnieniem granicznym opisano fenotyp hiperkinetycznego krążenia ze zwiększonym HR, SV i zwiększonym stężeniem noradrenaliny [16].

\section{Etiologia}

\section{Urodzeniowa masa ciała}

Opierając się na wynikach badań populacyjnych, wykazano ścisłą zależność między niską masą urodzeniową a zapadalnością na choroby układu krążenia w wieku dorosłym. Przedstawiono hipotezę, że mała masa urodzeniowa i niedożywienie wewnątrzmaciczne, poprzez powodowanie stresu metabolicznego i hiperkortyzolemii płodowej, indukują późniejszy rozwój AH i jego powikłań [17]. Kolejna teoria zakłada udział wrodzonej, mniejszej liczby nefronów w późniejszym rozwoju nadciśnienia i przewlekłej choroby nerek. Ponieważ u człowieka nefrony powstają tylko do 36 . tygodnia ciąży, związek między mniejszą liczbą nefronów a wcześniactwem i rozwojem AH w tej grupie osób wydaje się prawdopodobny [18]. Dokładniejsze analizy porównujące wpływ wielu czynników dowiodły, że wcześniactwo i dystrofia wewnątrzmaciczna tylko częściowo tłumaczą przyszłe ryzyko sercowo-naczyniowe i ryzyko rozwoju nadciśnienia samoistnego. Okazało się, że istotne znaczenie ma także szybki wzrost masy ciała w pierwszych 5 latach życia, co obserwuje się głównie u wcześniaków [19].

\section{Obciążenie rodzinne}

W długoletnich badaniach populacyjnych przeprowadzonych u dzieci i młodzieży wykazano, że ciśnienie tętnicze (BP, blood pressure) rodziców jest silnym czynnikiem determinującym ciśnienie ich potomków [20]. Obciążenie rodzinne nadciśnieniem samoistnym zakłada wpływ co najmniej dwóch czynników: genetycznego i środowiskowego, związanego ze stylem życia i z narażeniem na niekorzystne czynniki socjoekonomiczne [21, 22].

\section{Otyłość}

Ważnym parametrem antropometrycznym u osób w młodym wieku, w dużym stopniu determinującym wysokość BP, jest masa ciała [23]. Z analizy danych uzyskanych w badaniu NHANES (National Health and Nutrition Examination Survey), przeprowadzanym w Stanach Zjednoczonych, wynika, że istotne zwiększenie średnich wartości SBP i DBP u dzieci i młodzieży korelowało istotnie ze zwiększeniem wskaźnika masy ciała (BMI, body mass index) [4]. 
Polskie badania epidemiologiczne wykazały ścisły związek częstości zespołu metabolicznego z wiekiem badanych. W badaniu WOBASZ stwierdzono zespół metaboliczny u $10 \%$ mężczyzn oraz u $4 \%$ kobiet w wieku 20-39 lat oraz u 28\% mężczyzn i 24\% kobiet w wieku 40-59 lat. Najczęstszymi składowymi zespołu metabolicznego były: $\mathrm{AH}$, otyłość brzuszna oraz zwiększone stężenie triglicerydów [6].

W populacji pacjentów z otyłością trzewną, oprócz zaburzonego profilu lipidowego, węglowodanowego oraz $\mathrm{AH}$, stwierdza się także zaburzenia mikrokrążenia oraz przerost mięśnia sercowego i zwiększone ryzyko powikłań sercowo-naczyniowych [24-27]. Trzewna tkanka tłuszczowa wykazuje aktywność hormonalną i metaboliczną, co wynika z jej specyficznego unaczynienia przez system żyły wrotnej, większej liczby receptorów $\beta$-adrenergicznych, większej wrażliwości na aminy katecholowe oraz mniejszej na lipogenetyczne działanie insuliny. Tkanka tłuszczowa jest narządem hormonalnie czynnym, wytwarzającym szereg substancji biologicznie aktywnych, takich jak leptyna, adiponektyna, angiotensynogen, TNF- $\alpha$ oraz szereg innych cytokin prozapalnych i promiażdżycowych, spełniających ważną funkcję w regulacji BP i gospodarki węglowodanowo-lipidowej. Jednym z czynników hormonalnych niekorzystnego oddziaływania tkanki tłuszczowej trzewnej jest obecność izoformy $111 \beta$-dehydrogenazy steroidowej, enzymu katalizującego reakcję konwersji nieaktywnego kortyzonu do aktywnego kortyzolu [23].

\section{Stres}

Związek między występowaniem $\mathrm{AH}$ a stanem emocjonalnym pacjenta jest powszechnie znany. Najczęstszą niekardiologiczną przyczyną zgłaszania się do lekarza młodych dorosłych pacjentów są napady lęku, którym towarzyszy nagły niepokój, uczucie kołatania serca, podwyższone BP. Większość dotychczasowych badań potwierdziła udział zwiększonej aktywacji układu współczulnego w patogenezie AH [28-31]. Uważa się, że układ współczulny może być ogniwem łączącym stres psychiczny z występowaniem AH. Reakcja na stres może być uwarunkowana genetycznie i wiąże się z określonym typem osobowości, który cechuje się tłumioną wrogością powodującą zwiększenie aktywności współczulnej. W piśmiennictwie sugeruje się, że bodziec stresowy zwiększa stężenie adrenaliny we krwi i pobudza presynaptyczne receptory $\beta$ do wydzielania noradrenaliny [28]. Jednym z najlepiej zbadanych modeli przewlekłego stresu jest narażenie na obciążające bodźce związane $\mathrm{z}$ pracą zawodową. Wykazano, że u osób narażonych na stres w miejscu pracy istotnie wzrasta ryzyko rozwoju $\mathrm{AH}$.
W ciągu trzyletniej obserwacji stwierdzono wzrost SBP o $11,7 \mathrm{~mm} \mathrm{Hg}$ w porównaniu z osobami bez takiego obciążenia. U badanych wykazano również zwiększenie częstości występowania przerostu lewej komory (LVH, left ventricular hypertrophy). U mężczyzn narażonych na stres w czasie pracy, u których BP oceniano na podstawie całodobowej rejestracji, stwierdzono większe wartości BP nie tylko w pracy, ale także w domu [29]. Stres związany z pracą nabiera szczególnego znaczenia w warunkach współczesnego życia i często bezwzględnego współzawodnictwa, coraz większych wymagań dotyczących doskonalenia, braku stabilizacji i ryzyka utraty pracy.

W amerykańskich badaniach wykazano, że w grupie wiekowej 25-44 lata objawy lęku i depresji często wiązały się z AH. W piśmiennictwie odnotowuje się coraz większe zainteresowanie wpływem stresu na stan zdrowia oraz poszukiwanie wspólnych mechanizmów łączących etiologię zaburzeń lękowych oraz AH $[30,31]$. W ramach badania prospektywnego CARDIA (Coronary Artery Risk Development in Young Adults) obserwowano 3308 osób w wieku 18-30 lat z 4 aglomeracji miejskich USA. Po 5 latach częstość AH wynosiła u badanych $13,6 \%$, a po 15 latach $15 \%$. Co ciekawe, głównym czynnikiem korelującym $\mathrm{z}$ nadciśnieniem u młodych pacjentów był nie poziom lęku czy nasilenie depresji, ale poczucie presji czasu, niecierpliwość i uczucie wrogości. Z badań tych wynika, że ryzyko AH wiąże się bardziej z profilem osobowości i brakiem umiejętności radzenia sobie z emocjami niż z objawami lęku czy depresji [32]. Podkreśla się, że w zaburzeniach lękowych istotnym mechanizmem wspólnym z AH jest zwiększenie aktywności osi podwzgórzowo-przysadkowo-nadnerczowej z następowym zwiększeniem aktywności kortyzolu [29].

\section{Aktywacja układu renina-angiotensyna-aldosteron}

U normotensyjnego potomstwa osób z AH stwierdzono zmniejszenie przepływu nerkowego, co w konsekwencji prowadzi to do aktywacji układu renina-angiotensyna-aldosteron (RAA) $[17,18]$. Uważa się, że niska masa urodzeniowa oraz związane z nią zmniejszenie powierzchni filtracyjnej (mniejsza liczba kłębków nerkowych) predysponuje do wystąpienia $\mathrm{AH}$ [18]. Inna, niezwykle ciekawa hipoteza dotyczy „heterogeniczności kłębków nerkowych”. Zakłada ona, iż część kłębków nerkowych, na skutek niedokrwienia, ma zwiększone wydzielanie reniny, co prowadzi do wzrostu oporu nerkowego i w konsekwencji do zmniejszenia wydalania sodu przez pozostałe kłębki nerkowe [33-35]. 


\section{Wstępna ocena chorego i wskazówki diagnostyczne}

\section{Badanie podmiotowe}

Należy pamiętać, że wystąpienie u osoby w młodym wieku $\mathrm{AH}$, zwłaszcza o ciężkim przebiegu, powinno nasuwać podejrzenie jego wtórnego charakteru. Rozpoznanie nadciśnienia samoistnego polega na wykluczeniu jego wtórnych postaci.

Wywiad chorobowy powinien uwzględniać tryb życia, charakter i przebieg pracy zawodowej, stopień aktywności fizycznej oraz nawyków chorego z uwzględnieniem stosowanych używek (papierosy, alkohol, narkotyki). U kobiet konieczne jest ustalenie ewentualnego związku nadciśnienia ze stosowaniem doustnych środków antykoncepcyjnych. W badaniu podmiotowym u młodych dorosłych nie może zabraknąć wywiadu rodzinnego w kierunku AH oraz ustalenia występowania przedwczesnych zgonów z przyczyn sercowo-naczyniowych [36, 37].

\section{Badanie przedmiotowe}

U większości chorych na niepowikłane $\mathrm{AH}$ badanie przedmiotowe nie ujawnia istotnych odchyleń poza podwyższonym BP. Odchylenia w badaniu przedmiotowym są typowe dla nadciśnienia wtórego. U chorych na nadciśnienie uwarunkowane nadmiarem kortyzolu można stwierdzić zmiany zanikowe w obrębie skóry, czerwone rozstępy, nadmierne owłosienie, trądzik i skłonność do siniaczeń. Dla tej postaci nadciśnienia wtórnego typowa jest charakterystyczna otyłość centralna ze szczupłymi kończynami górnymi i dolnymi oraz „księżycowatą twarzą” i „,bawolim karkiem”.

U chorych z guzem chromochłonnym współistniejącym z nerwiakowłókniakowatością stwierdza się brunatne plamy na skórze i nerwiakowłókniaki.

Istotne znaczenie ma ocena tętna i osłuchiwanie tętnic. Asymetria tętna na tętnicach kończyn górnych, zwłaszcza u młodych kobiet, nasuwa podejrzenie nieswoistego zapalenia tętnic. Słabe wypełnienie lub brak tętna na tętnicach udowych budzi podejrzenie koarktacji aorty. Ważnym elementem badania jest ocena tętnic szyjnych, ponieważ ich zwężenie u osób młodych sugeruje dysplazję włóknisto-mięśniową. Stwierdzenie w nadbrzuszu szmeru naczyniowego wskazuje na zwężenie tętnicy lub tętnic nerkowych [36, 37].

Liczba danych dotyczących odrębności dokonywania pomiarów i klasyfikacji wysokości BP u młodych dorosłych jest obecnie ograniczona. Dlatego w tej grupie wiekowej stosuje się te same kryteria, co w populacji ogólnej.

Do uznanych metod pomiaru ciśnienia należą:

- kliniczne pomiary BP (tradycyjne, pomiary gabinetowe),

- samodzielne pomiary BP (pomiary domowe),
- całodobowa rejestracja ciśnienia tętniczego (ABPM, ambulatory blood pressure monitoring) [36-38].

Coraz więcej zwolenników znajdują pomiary przy użyciu zautomatyzowanych technik umożliwiających ocenę profilu zmian ciśnienia poza warunkami klinicznymi.

Do takich technik należy ABPM, które coraz częściej uznaje się za niezastąpione w rozpoznawaniu i leczeniu nadciśnienia. $\mathrm{U}$ młodych dorosłych pomiar BP może powodować nadmierną reakcję stresową, która u większości osób ma charakter chwilowy. Zazwyczaj obserwuje się ją u osób, u których następuje większy wzrost BP pod wpływem stresu psychicznego. Wykrycie tzw. AH białego fartucha jest niezmiernie ważne dla podjęcia właściwych decyzji terapeutycznych. Aby postawić właściwą diagnozę i podjąć odpowiednie decyzje terapeutyczne w powyższych sytuacjach klinicznych, konieczne jest wykonanie pomiaru BP metodą ABPM [38, 39].

Wyniki badań wskazują, że wysokość BP w ABPM jest silniejszym czynnikiem ryzyka chorobowości i śmiertelności sercowo-naczyniowej niż pomiary kliniczne [37]. Niezależnie od możliwości dokładniejszego przewidywania rokowania na podstawie ABPM, technika ta istotnie przyczyniła się do rozwoju wiedzy na temat nadciśnienia, ponieważ ujawniła zjawiska, których nie można było stwierdzić za pomocą pomiarów tradycyjnych. Należą do nich: brak nocnego spadku ciśnienia, nadciśnienie białego fartucha oraz nadciśnienie zamaskowane (masked hypertension) [36, 37].

\section{Szczególne postaci nadciśnienia tętniczego}

\section{Izolowane skurczowe}

Izolowane nadciśnienie skurczowe u młodych osób wiąże się ze zwiększoną $\mathrm{CO}$ i stosunkowo sztywnymi dużymi tętnicami, co może być spowodowane zwiększoną aktywnością układu współczulnego. Częstość występowania zaburzeń hemodynamicznych ocenia się na około $25 \%$ u młodych mężczyzn i na około $2 \%$ u kobiet. Wyniki badań wskazują na częstsze występowanie tej postaci nadciśnienia u młodych mężczyzn niepalących papierosów i charakteryzujących się dużą aktywnością fizyczną. Ponieważ wyniki większości badań obserwacyjnych wskazują na prawidłowe ciśnienie centralne przy jednoczesnym podwyższeniu ciśnienia na tętnicy ramiennej, często używa się terminu ,nadciśnienie tętnicze rzekome u młodych osób”. Niektórzy autorzy uważają, że IDH w młodym wieku jest początkowym etapem rozwoju IDH w latach późniejszych $[40,41]$. 


\section{Izolowane rozkurczowe}

Izolowane nadciśnienie rozkurczowe częściej występuje u młodych mężczyzn i wykazuje dodatnią zależność wraz ze wzrostem masy ciała oraz z częstością zespołu metabolicznego. U chorych z IDH obserwuje się zwiększony TPR [37, 42].

\section{Nadciśnienie zamaskowane}

Ostatnio coraz więcej uwagi poświęca się sytuacji odwrotnej, gdy wartości BP w pomiarach klinicznych są prawidłowe, a w całodobowej rejestracji — podwyższone. Rozpoznaje się wówczas nadciśnienie tętnicze zamaskowane (ukryte). Szacuje się, że jego częstość u młodych dorosłych wynosi co najmniej 10\%, z tendencją do zmniejszania się wraz z wiekiem.

Jak wynika z przeprowadzonych badań, nadciśnienie tętnicze zamaskowane występuje częściej u młodych mężczyzn z większą częstością HR. Postuluje się, że ta postać nadciśnienia może być związana z większą aktywnością fizyczną badanych i większym obciązeniem pracą zawodową [43].

Nadciśnienie zamaskowane stawia klinicystów przed ważnym problemem identyfikacji osób z tym stanem. Niewątpliwie nie ma praktycznych możliwości wykonania ABPM u wszystkich osób z prawidłowym ciśnieniem w warunkach klinicznych. Natomiast jego niewykrycie może mieć poważne konsekwencje zdrowotne dla pacjentów.

Ponieważ nie ma żadnych wyraźnych cech pozwalających rozróżnić osoby ze zwiększonym prawdopodobieństwem nadciśnienia zamaskowanego, pozostaje jedynie analizować cechy mogące wskazywać na ten stan. W badaniach epidemiologicznych u prawie połowy młodych osób z utrzymującym się nadciśnieniem zamaskowanym stwierdzono obciążające wywiady rodzinne w kierunku nadciśnienia. Ponadto stwierdzono, że ten związek był jeszcze silniejszy, kiedy nadciśnienie wystąpiło u rodziców w młodym wieku. Podkreśla to znaczenie przeprowadzania szczegółowego wywiadu rodzinnego u pacjentów z chorobami układu sercowo -naczyniowego. Młodzi dorośli z nadciśnieniem zamaskowanym byli najczęściej otyli i mieli cechy otyłości centralnej. W badaniach, w których ocenia się zależności między otyłością a nadciśnieniem zamaskowanym, ważne jest mierzenie ciśnienia za pomocą mankietu o odpowiedniej wielkości, ponieważ zastosowanie zbyt małego mankietu do ABPM mogłoby zawyżyć wartości i spowodować, że zostaną błędnie uznane za nadciśnienie zamaskowane. U pacjentów z zamaskowanym nadciśnieniem obserwuje się najczęściej większą średnią częstość HR niż u osób normotensyjnych. Może to wskazywać na większą reaktywność na bodźce stresowe dnia codziennego lub na wpływ pozycji stojącej.
Ponieważ częstość występowania nadciśnienia zamaskowanego i jego odwrotnego zjawiska, czyli nadciśnienia białego fartucha, szacuje się łącznie na $20 \%$ młodych osób, stwarza to niebezpieczeństwo ustalenia błędnego rozpoznania w dużej grupie pacjentów [43]. Niestety, z uwagi na brak odpowiednich danych, dużym problemem są kryteria włączenia odpowiedniego leczenia. Decyzja o wdrożeniu odpowiedniego leczenia zależy od całego profilu ryzyka oraz postrzeganej potrzeby ochrony układu sercowo-naczyniowego przed następstwami nadciśnienia [37].

\section{Ryzyko sercowo-naczyniowe}

W badaniu FHS (Framingham Heart Study) wykazano, że chorzy, u których w wieku 40 lat stwierdzono AH, mają krótszą oczekiwaną długość życia (o 6,8 roku w przypadku mężczyzn i o 7,3 roku w przypadku kobiet) od tych z optymalnym lub prawidłowym ciśnieniem. $Z$ badań epidemiologicznych wynika, że osoby $\mathrm{w}$ wieku 40-49 lat $\mathrm{z}$ ciśnieniem $\geq 115 / 75 \mathrm{~mm} \mathrm{Hg}$ mają ciągłą liniową zależność między wartościami SBP i DBP a ryzykiem wystąpienia zdarzeń sercowo-naczyniowych $[2,44]$. Ponadto udowodniono, że AH w grupie wiekowej 15-49 lat jest jedną z podstawowych przyczyn udarów mózgowych [45]. Ocena ryzyka sercowo-naczyniowego dostarcza informacji o konieczności zmiany stylu życia i podjęcia leczenia farmakologicznego. Przekaz stopnia ryzyka powinien być nie tylko prosty i czytelny, ale również umożliwiać młodej osobie wyobrażenie sobie rzeczywistego ryzyka braku zmian w stylu życia i niestosowania leczenia farmakologicznego. Ze względu na niskie bezwzględne ryzyko wystąpienia zdarzeń sercowo-naczyniowych u osób w młodym wieku, w zaleceniach dotyczących prewencji zdarzeń sercowo-naczyniowych zaproponowano, aby ryzyko względne podawać w odniesieniu do osoby w tym samym wieku $\mathrm{z}$ idealnym profilem czynników ryzyka. Na przykład, u mężczyzny w wieku 40 lat, palącego papierosy, z SBP równym $160 \mathrm{~mm} \mathrm{Hg}$ i całkowitym stężeniem cholesterolu wynoszącym $230 \mathrm{mg} / \mathrm{dl}$ bezwzględne ryzyko według skali SCORE (systematic coronary risk evaluation) wynosi zaledwie $4 \%$. Natomiast ryzyko względne, porównujące jego profil z profilem osoby w tym samym wieku, ale niepalącej, z prawidłowym BP i prawidłowym stężeniem cholesterolu, jest sześciokrotnie większe [46].

Inne sposoby oceny i przedstawienia młodej osobie ryzyka sercowo-naczyniowego mogą polegać na podaniu szacunkowego wieku, w którym prawdopodobnie wystąpią powikłania sercowo-naczyniowe lub na podaniu przewidywanej długości życia [47]. 


\section{Badania laboratoryjne i obrazowe}

W postępowaniu diagnostycznym istotne znaczenie mają badania laboratoryjne, ponieważ umożliwiają ocenę ryzyka sercowo-naczyniowego, powikłań narządowych oraz rozpoznanie wtórnych postaci AH. Zgodnie z wytycznymi Polskiego Towarzystwa Nadciśnienia Tętniczego (PTNT), ale także europejskimi zaleceniami, badania dodatkowe podzielono na podstawowe i rozszerzone [36, 37]. Podstawowe badania należy wykonać u każdego chorego z nowo wykrytym $\mathrm{AH}$.

\section{Zasady postępowania}

\section{Leczenie niefarmakologiczne}

Leczenie niefarmakologiczne, określane również jako modyfikacja stylu życia, jest nieodłącznym elementem postępowania leczniczego u chorych na AH. Odgrywa ono także ważną rolę w prewencji nadciśnienia i innych chorób sercowo-naczyniowych u osób z prawidłowym ciśnieniem. Największe znaczenie ma kompleksowe zastosowanie wszystkich dostępnych metod.

U młodych dorosłych postępowanie niefarmakologiczne jest podstawową formą leczenia hipotensyjnego. Dopiero jeżeli po 3-6 miesiącach stosowania się do zaleceń niefarmakologicznych nie udaje się uzyskać docelowego ciśnienia, modyfikację stylu życia należy uzupełnić o farmakoterapię. Podobnie jak w ogólnej populacji leczenie niefarmakologiczne obejmuje normalizację masy ciała, zwiększenie aktywności fizycznej, ograniczenie spożycia soli kuchennej, zaprzestanie palenia tytoniu i ograniczenie spożycia alkoholu oraz używek mogących podwyższać BP [36, 37].

\section{Postepowanie farmakologiczne Zasadność farmakoterapii na podstawie EBM}

Wiek jest istotnym czynnikiem szacowania korzyści i opłacalności leczenia $\mathrm{AH}$, co jest zasadniczym powodem braku dużych badań klinicznych wśród młodych pacjentów. $U$ chorych młodych i obciążonych małym ryzykiem korzyść z leczenia w ciągu 5 lat jest niewielka, a taki właśnie okres przyjmuje się w większości badań z randomizacją oceniających kliniczne punkty końcowe. Dlatego też w takich badaniach wyklucza się udział osób młodych.

Należy mieć świadomość, że celem krótkoterminowym u takich pacjentów nie jest zapobieganie incydentom sercowo-naczyniowym i spowodowanym przez nie zgonom, ponieważ są one mało prawdopodobne. Właściwym celem leczenia hipotensyjnego u młodych chorych powinno być zapobieganie postępowi nadciśnienia i wystąpieniu lub progresji subklinicznych uszkodzeń narządowych, które ostatecznie prowadzą do jawnej choroby sercowo-naczyniowej i śmierci. Wynika z tego, że chociaż wczesne wdrożenie leczenia przeciwnadciśnieniowego u osób młodych mogłoby być bardzo korzystne, to korzyść jest odroczona i trudna do oszacowania tradycyjnymi metodami. Być może w tej kwestii pomocne byłoby opracowanie bardziej rygorystycznych i lepiej zweryfikowanych metod oceny znaczenia rokowniczego markerów biologicznych i subklinicznych uszkodzeń narządowych.

Nie jest jasne, czy osoby starsze i osoby w młodym wieku odnoszą podobne korzyści z farmakologicznego leczenia przeciwnadciśnieniowego ani czy wybór leków powinien zależeć od wieku pacjenta. Próbę wyjaśnienia tych zagadnień podjął zespół badaczy BPLTTC (blood pressure lowering treatment trialists' collaboration), który porównał względne obniżenie $\mathrm{BP}$ i zmniejszenie ryzyka sercowo-naczyniowego uzyskiwane w różnych schematach leczenia hipotensyjnego u młodszych dorosłych i u osób starszych. Badacze ci dokonali metaanalizy 31 randomizowanych badań klinicznych, obejmujących 190606 chorych, porównując względne zmniejszenie ryzyka w wyniku stosowania różnych grup leków hipotensyjnych u młodszych dorosłych $(<65$ lat) i u osób starszych ( $\geq 65$ lat). Powyższe przedziały wiekowe wybrano dlatego, że w większości badań uwzględnionych $\mathrm{w}$ metaanalizie przyjęto te same kategorie do analiz w podgrupach. Nie stwierdzono znamiennych różnic między grupami wiekowymi pod względem efektu hipotensyjnego ani liczby poważnych incydentów sercowo-naczyniowych. Nie było też znamiennej interakcji między wiekiem a wynikami leczenia, gdy wiek analizowano jako zmienną ciągłą i porównywano ogólne efekty leczenia w różnych badaniach. Badacze wysnuli wniosek, że obniżenie BP daje korzyści zarówno u młodszych dorosłych, jak i u osób starszych oraz że nie ma sprawdzonych informacji wskazujących na znamienne różnice $\mathrm{w}$ skuteczności zapobiegania poważnym incydentom sercowo-naczyniowym przez poszczególne grupy leków w zależności od wieku [48].

Główne wnioski, ważne dla lekarzy praktyków, wynikające z metaanalizy BPLTTC to:

1. Obniżenie BP daje podobne proporcjonalne zmniejszenie ryzyka incydentów naczyniowych u młodszych i starszych dorosłych, z zastrzeżeniem, że mało danych dotyczy chorych poniżej 50. roku życia.

2. Bezwzględne korzyści z leczenia są prawdopodobnie większe u osób starszych, ponieważ mają oni duże ryzyko bezwzględne.

3. Nie ma przekonujących danych uzasadniających preferowanie leków z określonych grup u młodszych albo u starszych dorosłych.

Należy pamiętać, że u niektórych pacjentów bezpieczeństwo jest kwestią priorytetową, na przykład u ko- 




Rycina 1. Wybór leków hipotensyjnych w zależności od wieku chorego. ACE (angiotensin-converting enzyme) — inhibitor enzymu konwertującego angiotensynę; ARB (angiotensin receptor blocker) — antagonista receptora angiotensyny; ARO — aktywność reninowa osocza; CCB (calcium channel blocker) - antagonista wapnia; CVD (coronary vascular disease) — choroby sercowo-naczyniowe; GFR (glomerular filtration rate) - przesączanie kłębuszkowe; RAA (renin-angiotensin-aldosterone system) - układ renina-angiotensyna-aldosteron; SNS (sympathetic nervous system) —układ współczulny (opracowano na podstawie: J. Hypertens. 2009; 27: 1719-1742, Am. J. Hypertens 2009; 22: 531-537)

biet w wieku prokreacyjnym, u których leki blokujące układ RAA są przeciwwskazane ze względu na ryzyko zaburzeń rozwojowych płodu.

\section{Dobór leków hipotensyjnych w zależności od wieku}

Podejmując decyzję o leczeniu farmakologicznym młodego, aktywnego zawodowo pacjenta z AH, należy rozwiązać dwa problemy: przekonać chorego do konieczności leczenia nadciśnienia i przestrzegania zaleceń oraz wybrać optymalną terapię hipotensyjną.

Przeprowadzone metaanalizy jednoznacznie wskazują, że skuteczne obniżenie BP nie może być jedynym celem terapii. Leczenie hipotensyjne powinno poprawić jakość życia, wywierać korzystny wpływ na zaburzenia hemodynamiczne i metaboliczne oraz prowadzić do regresji wtórnych do nadciśnienia zmian narządowych, co w przyszłości spowoduje zmniejszenie chorobowości i śmiertelności w tej grupie chorych.

Jak przedstawiono na rycinie 1, uwzględniając obowiązujące zalecenia oraz ewolucję zmian patofizjologicznych nadciśnienia, u pacjentów w wieku poniżej 55 lat lekiem pierwszego rzutu w początkowym okresie terapii powinien być inhibitor enzymu konwertującego angiotensynę (ACE, angiotensin-converting enzyme) lub antagonista receptora angiotensyny (ARB, angiotensin receptor blocker). U pacjentów z nadciśnieniem w wieku 55 lat i starszych lekiem pierwszego wyboru powinien być antagonista wapnia $(\mathrm{CCB}$, calcium channel blocker) lub diuretyk tiazydowy.

W badaniach prowadzonych przez Departament ds. Weteranów (Department of Veterans Affairs) w Stanach
Zjednoczonych stwierdzono, że diuretyki tiazydowe były skuteczniejsze u pacjentów starszych niż u młodszych, a w szczególności miały większy wpływ na SBP u chorych w starszym wieku. W badaniu Department of Veterans Affairs Single-drug Therapy of Hypertension Study u mężczyzn wiek i rasa miały ważny wpływ na skuteczność monoterapii nadciśnienia. Antagoniści wapnia skuteczniej niż inne leki obniżały ciśnienie u starszych chorych, zwłaszcza rasy czarnej. U młodszych osób rasy białej najskuteczniejsze były inhibitory ACE, natomiast najmniej skuteczne okazały się diuretyki. Co ciekawe, wiek i rasa były najmocniejszym predyktorem odpowiedzi na leczenie [49].

\section{Inbibitor ACE - optymalny wybór}

Inhibitory konwertazy angiotensyny stanowią rozbudowaną grupę leków hipotensyjnych, różniących się od siebie budową chemiczną oraz farmakokinetyką, która warunkuje czas ich działania hipotensyjnego oraz efekty pozahipotensyjne. Oprócz hamowania układu RAA, leki te charakteryzują się również działaniem modulującym układ kalikreina-kininy, powodując zahamowanie degradacji bradykininy i wzmocnienie efektu naczyniorozszerzającego tej substancji. Powyższe dwa główne mechanizmy są w dużej mierze odpowiedzialne za ich kardio- i nefroprotekcyjne działanie. Mechanizm bradykininowy, typowy tylko dla inhibitorów ACE, stanowi o ich przewadze nad sartanami w prewencji sercowo-naczyniowej [36].

W metaanalizie Savarese i wsp., obejmującej 108233 pacjentów (26 badań), wykazano, że inhi- 
bitory ACE znamiennie, bo o $15 \%$, obniżały ryzyko wystąpienia pierwszorzędowego punktu końcowego (zgon z przyczyn sercowo-naczyniowych, zawał serca, udar mózgu) oraz o $8 \%$ zmniejszały ryzyko śmiertelności z wszystkich przyczyn. Wśród inhibitorów ACE wyróżniał się perindopril, który był jedynym lekiem istotnie zmniejszającym częstość występowania pierwszorzędowego punktu końcowego oraz zdarzeń sercowo -naczyniowych (zawał serca i niewydolność serca) [50].

Lekarz praktyk zwykle staje przed dylematem wyboru optymalnego preparatu dla swojego chorego. Rozpoczynając terapię u młodego, aktywnego zawodowo mężczyzny, szczególnie ważne jest, aby był to lek skuteczny, dobrze tolerowany i dawkowany jeden raz na dobę, co daje dużą szansę, że pacjent nie zrezygnuje $\mathrm{z}$ leczenia. Aktualne wytyczne podkreślają, że podstawowym celem terapii pacjenta z AH jest zmniejszenie śmiertelności oraz globalnego ryzyka powikłań sercowo-naczyniowych i nerkowych [36, 37]. Z punktu widzenia medycznego ważne jest, aby stosowany lek miał dowody EBM (evidence based medicine) potwierdzające jego właściwości plejotropowe, gwarantujące ochronę narządową i wydłużenie życia oraz dający możliwość kontynuowania terapii preparatem złożonym.

Ze wszystkich inhibitorów ACE najlepiej przebadanym lekiem, spełniającym wszystkie powyższe kryteria, jest perindopril.

a) Perindopril: inhibitor ACE o udowodnionym dziataniu hipotensyjnym $i$ doskonatej tolerancji, gwarantującej wysoki „compliance”

Dowody na jego wysoką skuteczność hipotensyjną i dobrą tolerancję pochodzą z badania o akronimie CONFIDENCE (The Efficacy and Tolerability of Coversyl now for Patients with Hypertension: Evidence-Based Medicine). Było to prospektywne, wieloośrodkowe badanie obserwacyjne przeprowadzone w grupie 8298 chorych na AH: 56\% nadciśnienie świeżo zdiagnozowane, a w 44\% — źle kontrolowane. Po 12 tygodniach leczenia stwierdzono dobrą tolerancję, wysoki compliance i dużą efektywność hipotensyjną leku zależną od zastosowanej dawki [51].

Inhibitory ACE to grupa leków o dobrej tolerancji, a najczęściej opisywanym w piśmiennictwie objawem niepożądanym związanym $\mathrm{z}$ ich stosowaniem jest suchy kaszel. Indukowany aktywnością inhibitora ACE wzrost stężenia bradykininy w łożysku płucnym prawdopodobnie wpływa na pojawienie się kaszlu jako jednego z działań niepożądanych terapii. Wysokie powinowactwo do bradykininy $i$ istotny wzrost jej aktywności $\mathrm{w}$ przebiegu leczenia perindoprilem powinno znacząco zwiększać częstość kaszlu jako objawu niepożądanego, tymczasem w badaniach wykazano, że preparat ten charakteryzuje się jednym z najniższych wskaźników występowania kaszlu w grupie inhibito- rów ACE [52]. Wyjaśnienia tego pozornego paradoksu podjęli się Ceconi i wsp. w analizie wyników badania PERTINENT (Perindopril-Thrombosis, InflammatioN, Endothelial Dysfunction and Neurohormonal Activation Trial), stwierdzając, że pomimo wysokiego powinowactwa do bradykininy lek utrzymywał stężenie tej substancji w zakresach właściwych dla osób zdrowych, co może tłumaczyć niską częstość występowania kaszlu [53].W ostatnim czasie ukazała się ciekawa publikacja Bangalore i wsp. porównująca częstość kaszlu opisywaną w literaturze i zgłaszaną przez lekarzy jako działanie niepożądane podczas leczenia różnymi inhibitorami ACE. W metodyce uwzględniono wszystkie randomizowane, kliniczne badania publikowane w dostępnych bazach od 1990 roku. Do analizy włączono 198130 pacjentów. We wnioskach autorzy podkreślają, że incydenty kaszlu, jak i odstawienie leku zależne od kaszlu, jest siedmiokrotnie częściej opisywane w literaturze niż stwierdzane w rzeczywistości. W przypadku perindoprilu wycofanie się ze stosowania preparatu występowało jedynie u 1,3\% badanych [54].

Powodem odmowy leczenia AH przez młodych mężczyzn jest obawa przed zaburzeniami potencji, kojarzonymi z lekami hipotensyjnymi. Zaburzenia erekcji występują częściej u pacjentów z AH niż z prawidłowymi wartościami ciśnienia. Dysfunkcję seksualną uważa się za niezależny czynnik ryzyka sercowo-naczyniowego i możliwy wykładnik toczącego się procesu miażdżycowego [55]. W badaniach wykazano, że klasyczne $\beta$-adrenolityki i diuretyki tiazydowe zwiększają ryzyko zaburzeń erekcji u mężczyzn [56]. W porównaniu z nimi inhibitory ACE i sartany mają korzystny wpływ na erekcję i dlatego te grupy preparatów, zgodnie z wytycznymi PTNT 2015, stanowią leki pierwszego wyboru u osób z dysfunkcją seksualną [36].

\section{b) Perindopril: dtugodziatający inbibitor ACE, zapewniający catodobowa skuteczność}

Zgodnie z obowiązującymi wytycznymi Europejskiego Towarzystwa Nadciśnienia Tętniczego (ESH, European Society of Hypertension), Europejskiego Towarzystwa Kardiologicznego (ESC, European Society of (ardiology) i PTNT zalecane jest stosowanie leków zapewniających całodobową skuteczność przy podawaniu raz dziennie [36, 37]. Do zalet takich leków należą: lepsze przestrzeganie zaleceń terapeutycznych oraz minimalizacja zmienności ciśnienia.

\section{Poprawa przestrzegania zaleceń terapeutycznych}

Wyniki badań dotyczących przestrzegania zaleceń terapeutycznych przez pacjentów o różnych zawodach jednoznacznie wskazują, że podawanie leków w kilku dawkach wpływa na gorsze stosowanie się do wskazówek lekarza. Oceniano to na podstawie liczby tabletek oraz za pomoca systemu MEMS (Medical Event Monitoring System), rejestrującego każde otwarcie opako- 


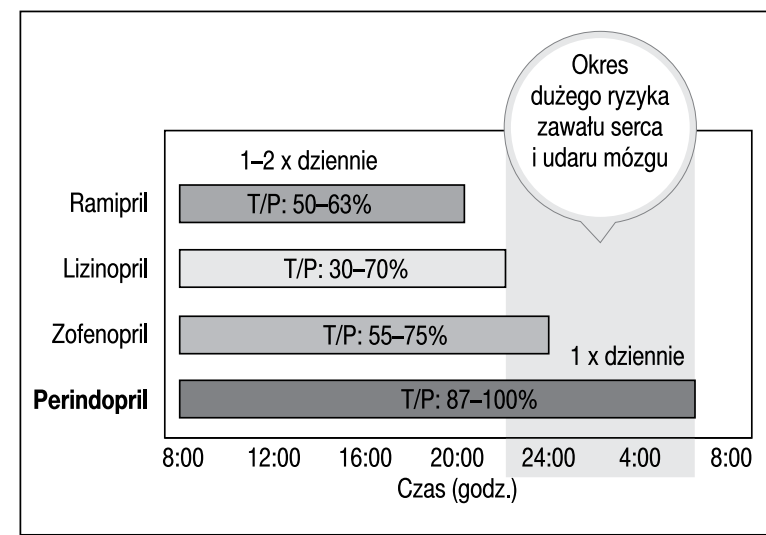

Rycina 2. Wartość wskaźnika T/P według FDA dla wybranych inhibitorów ACE (opracowano podstawie: N. Engl. J. Med. 1993; 328: 914-921; J. Hypertens. 1995; 18: 1105-1112; Am. J. Hypertens. 1996; 9: 76S-82S)

wania jako wskaźnik przyjęcia leku. Wspomniane badania dowiodły, że aby zrozumieć potencjalny wpływ słabej współpracy chorych na ABPM należy wziąć pod uwagę zarówno okres przerwy pomiędzy kolejnymi dawkami, jak i czas działania poszczególnych preparatów hipotensyjnych [57].

Właściwa kontrola $w$ godzinach porannych zmniejszająca ryzyko wystąpienia epizodów sercowo-naczyniowych

Stwierdzenie, że rzadsze dawkowanie leków w ciągu doby sprzyja długoterminowemu przestrzeganiu zasad terapii, doprowadziło do stworzenia przez niektóre firmy farmaceutyczne długodziałających wersji leków. Instytucje nadzoru, takie jak Amerykańska Agencja ds. Żywności i Leków (FDA, Food and Drug Administration), uznały, że zbyt duży spadek BP, w szczytowej fazie działania leku po przekroczeniu dawki, może być szkodliwy. Ze względu na te obawy powstał doraźny komitet doradczy FDA, który zaproponował wprowadzenie wskaźnika T/P (trough:peak ratio) jako arytmetycznego wykładnika efektu hipotensyjnego leku w okresie między kolejnymi dawkami. Wskaźnik ten określa się jako stosunek obniżenia BP w 24 godziny po przyjęciu poprzedniej dawki leku do maksymalnej redukcji BP w szczytowej fazie działania medykamentu. Obie wielkości należy skorygować względem zmian wartości ciśnienia pod wpływem placebo. Minimalną, wymaganą przez FDA wartość wskaźnika określono na poziomie $50 \%$, przy czym najlepiej, aby była ona bliska 100\% [58-60].

Doniesienia z ostatnich lat wskazują, że znaczny i nagły wzrost ciśnienia w godzinach porannych (tzw. morning surge) zwiększa stopnień uszkodzenia narządów oraz częstość incydentów sercowo-naczyniowych u chorych z AH [61-63]. Ponadto dowiedziono, że niekorzystne zdarzenie jest najbardziej prawdopodobne

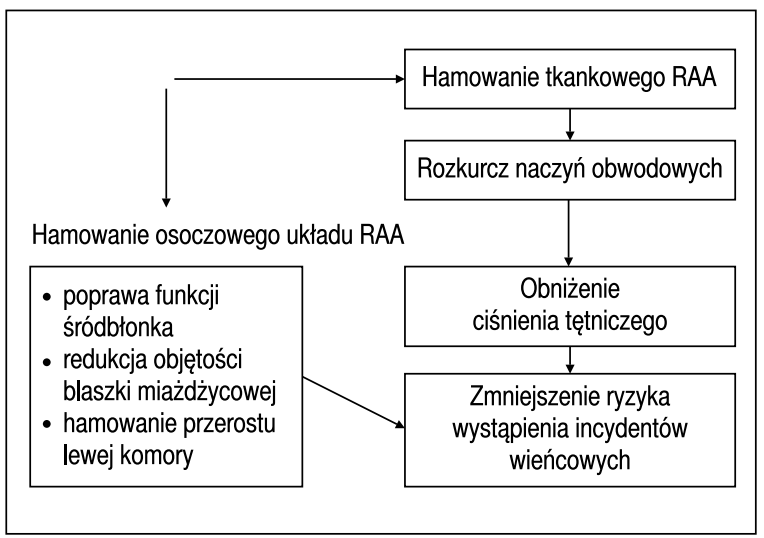

Rycina 3. Schemat efektu osoczowego i tkankowego działania inhibitora ACE (opracowano na podstawie: Hypertension 2003; 41: 1-6; Circulation 2010; 121: 1768-1777; Am. Coll. Cardiol. 2013; 61: 131-142)

w godzinach porannych, pomiędzy 6.00 a 10.00 [64]. Leczenie $\mathrm{AH}$ preparatami dawkowanymi raz dziennie i wykazującymi 24-godzinne działanie przeciwdziała nagłemu wzrostowi BP w godzinach porannych następnej doby. Perindopril spełnia kryterium 24-godzinnej skuteczności i całodobowej ochrony narządowej, a jego wskaźnik T/P w zależności od wybranej metodologii wynosi od 87 do $100 \%$.

Na rycinie 2 przedstawiono wartość wskaźnika T/P wg FDA dla niektórych inhibitorów ACE.

\section{c) Perindopril - dziatanie przeciwmiażḋycowe, przeciwzakrzepowe, antyproliferacyjne}

Prace doświadczalne wskazują na wielokierunkowy wpływ angiotensyny II na różne etapy procesu miażdżycowego i dlatego postuluje się, aby omawiany hormon uznać za czynnik rozwoju miażdżycy i chorób układu sercowo-naczyniowego. Przyjmuje się, że związek pomiędzy angiotensyną II a miażdżycą zależy głównie od aktywności tkankowych elementów układu RAA. Miejscowe wytwarzanie angiotensyny II jest odpowiedzialne za autokrynne (miejscowe działanie na te same komórki) i parakrynne (na sąsiednie komórki). Uważa się, że osoczowy układ RAA stanowi jedynie $10 \%$ jego aktywności i odgrywa rolę w krótkoterminowej regulacji czynności układu sercowo-naczyniowego, ulegając aktywacji w przebiegu ostrej hipotonii czy niewydolności serca. Zadaniem tego układu jest „przywracanie właściwego ciśnienia tętniczego i homeostazy serca”, a po osiągnięciu kompensacji jego aktywność ulega zmniejszeniu. Tkankowy układ renina-angiotensyna (stanowiący $90 \%$ ) pozostaje stale pobudzony, a ciągła aktywacja angiotensyny II i rozpad bradykininy sprzyja wtórnym, niekorzystnym zmianom strukturalnym w sercu i naczyniach krwionośnych [65]. Schematyczne efekty działania osoczowego i tkankowego inhibitorów ACE przedstawiono na rycinie 3. 


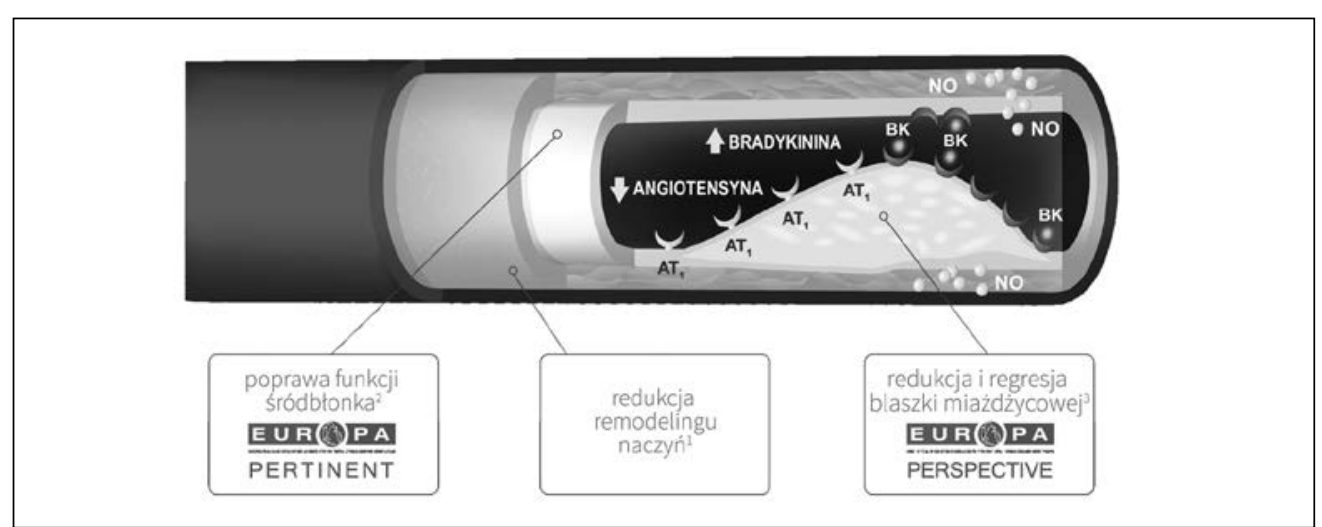

Rycina 4. Schematyczne przedstawienie naczynioprotekcyjnego działania perindoprilu. NO — tlenek azotu, BK — bradykinina, AT1 — receptor 1 dla angiotensyny II (opracowano na podstawie: Cardiovasc. Res. 2007; 73: 237-246; Am. J. Cardiol. 2007; 100: 159-163)

Wspólną cechą osoczowych i tkankowych inhibitory ACE jest: korzystny efekt hemodynamiczny i neurohormonalny oraz korzystny wpływ na gospodarkę węglowodanową i lipidową. Dodatkowe korzyści wynikające ze stosowania inhibitora „tkankowego" to poprawa funkcji śródbłonka, działanie przeciwzakrzepowe, fibrynolityczne, przeciwmiażdżycowe i antyproliferacyjne [65]. We współczesnych zaleceniach dotyczących terapii AH podkreśla się, że nowoczesny lek hipotensyjny powinien wpływać na procesy krzepnięcia, fibrynolizy, miażdżycy, remodeling serca i naczyń oraz poprawę funkcji śródbłonka. Na podstawie przedstawionych danych, na miano nowoczesnych leków hipotensyjnych zasługują tkankowe, długo działające inhibitory ACE, wśród nich jako najlepiej przebadany należy wyróżnić perindopril [36].

W badaniu o akronimie EUROPA (The EURopean trial On reduction of cardiac events with Perindopril in stable coronary Artery disease) zaobserwowano podobny wpływ leczenia perindoprilem na poprawę rokowania sercowo-naczyniowego zarówno u chorych z AH, jak i bez nadciśnienia. Ponadto wpływ tego leku na zmniejszenie liczby zdarzeń sercowo-naczyniowych był większy, niż można było się spodziewać przy obserwowanym obniżeniu BP [66]. Wyniki tego badania wskazywały, że nie można lekceważyć swoistego przeciwmiażdżycowego działania perindoprilu, a dla pewności dowodów zaplanowano subanalizę badania EUROPA o akronimie PERTINENT (PERindopril -Thrombosis, InflammatioN, Endothelial dysfunction and Neurohormonal activation Trial) skupiającą się na rozwoju miażdżycy i funkcji śródbłonka. Wykazano, że perindopril chroni śródbłonek naczyniowy pacjentów ze stabilną chorobą wieńcową, co poprawia jego funkcję oraz zapobiega wystąpieniu i progresji zmian miażdżycowych. Efekt ochronny śródbłonka wywierany przez perindopril wynika z hamowania apoptozy komórek endotelium oraz ze stymulującego wpływu na ekspresję i aktywność syntazy tlenku azotu [53]. W piśmiennictwie podkreśla się również protekcyjne działanie perindoprilu na ścianę tętnic. W badaniu PERSPECTVE (Perindopril'S Prospective Effect on Coronary aTherosclerosis by angiography and IntraVascular ultrasound Evaluation) wykazano, że w populacji normotensyjnych chorych ze stabilną chorobą wieńcową stosowanie perindoprilu istotnie wpływa na zahamowanie, a po zwiększeniu dawki także na regresję niezwapniałych blaszek miażdżycowych $\mathrm{w}$ tętnicach wieńcowych [67]. Na rycinie 4 przedstawiono schemat naczynioprotekcyjnego działania perindoprilu.

\section{d) Perindopril daje gwarancje skutecznej prewencji} pierwotnej i ochrony narządowej w przysztości

Dowodów na skuteczność perindoprilu w ochronie narządowej dostarczył wieloośrodkowy, randomizowany, kontrolowany placebo program EUROPA. Spośród wielu celów badania jednym z najważniejszych było prześledzenie wpływu przewlekłego podawania peryndoprilu między innymi na pierwszorzędowy punkt końcowy obejmujący: zgon z przyczyn sercowo-naczyniowych, zawał serca niezakończony zgonem lub zatrzymanie krążenia ze skuteczną resuscytacją. Autorzy tego badania pokreślili, że wybrali perindopril, długo działający inhibitor enzymu konwertującego, ponieważ poza właściwościami hipotensyjnymi ma on działanie przeciwniedokrwienne i przeciwmiażdżycowe oraz wpływa na remodeling sercowo-naczyniowy [66].

Stosowanie perindoprilu wiązało się ze znamiennym zmniejszeniem częstości występowania pierwszorzędowego punktu końcowego. Należy podkreślić, że korzystny efekt zaczął uwidaczniać się po upływie roku i stopniowo zwiększał się z czasem trwania badania. Stopniowe pojawienie się działania i narastanie korzyści z czasem jest zbieżne z przeciwmiażdżycowym i przeciwnadciśnieniowym działaniem inhibitorów ACE i pozwala wnioskować, że im dłuższe leczenie 


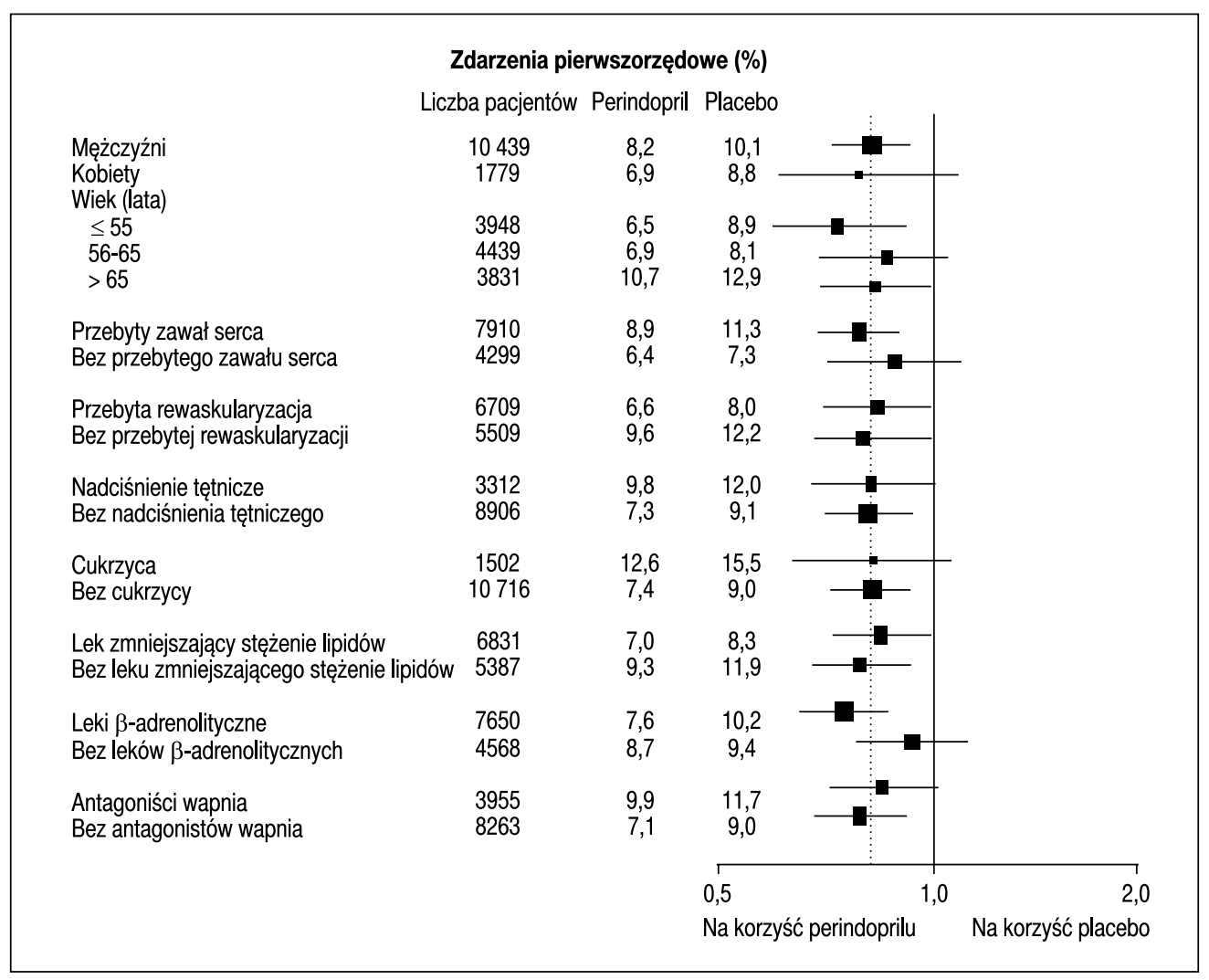

Rycina 5. Korzystny wpływ perindoprilu niezależnie od leczonych subpopulacji w badaniu EUROPA (opracowano na podstawie: Lancet 2003; 362: 782-788)

perindoprilem, tym skuteczniejsza prewencja incydentów sercowo-naczyniowych.

Jak przedstawiono na rycinie 5 , analizując podgrupy chorych, stwierdzono, że korzystny wpływ perindoprilu był widoczny we wszystkich grupach wiekowych, u pacjentów z nadciśnieniem i bez nadciśnienia, z cukrzycą i bez cukrzycy, z przebytym zawałem i bez zawału serca. W kontekście leczenia młodego chorego warto zauważyć, że największe korzyści zdrowotne z leczenia perindoprilem odniosła podgrupa pacjentów poniżej 55. roku życia.

e) Perindopril idealny partner w terapii skojarzonej

Najnowsze dane wskazują, że tylko u około $50 \%$ leczonych udaje się osiągnąć docelowe wartości BP. Wśród wielu przyczyn niepowodzenia monoterapii wymienia się: wysokie wartości ciśnienia przed rozpoczęciem leczenia, mechanizmy kompensacyjne, przeciążenie objętościowe i nieprzestrzeganie zaleceń terapeutycznych [68].

Według aktualnych wytycznych w przypadku konieczności stosowania terapii skojarzonej należy preferować preparaty złożone, których podstawą jest lek blokujący układ RAA [26]. Szacuje się, że około 30\% pacjentów do osiągnięcia dobrej kontroli ciśnienia wymaga co najmniej trzech preparatów. W niepo- wikłanym $\mathrm{AH}$ podstawową terapią trójlekową jest połączenie leku blokującego układ RAA, antagonisty wapnia i diuretyku tiazydowego/tiazydopodobnego [36]. Szczególną wartość mają takie preparaty złożone, które posiadają trzy cechy: po pierwsze, oparte są na lekach składowych o udowodnionym wpływie na redukcję ryzyka sercowo-naczyniowego, szczególnie w skojarzeniu, po drugie, oba leki składowe maja wysoki wskaźnik T/P, zapewniający równomierną, całodobową kontrolę ciśnienia, po trzecie, występują w kilku dawkach, co pozwala na zwiększanie dawki wybranego leku w preparacie złożonym. Te cechy uzyskuje się prze skojarzeniu perindoprilu z indapamidem lub amlodipiną. Należy podkreślić, że perindopril, który jest „bohaterem” znanych prób klinicznych przeprowadzonych w dużch grupach pacjentów: ASCOT, ADVANCE, PROGRESS, oraz licznych metaanaliz w populacjach chorych na $\mathrm{AH}$, ma niepodważalne i najlepsze dowody EBM ze wszystkich inhibitorów ACE oraz jest idealnym partnerem w leczeniu skojarzonym [69-72]. Daje to możliwość kontynuowania terapii preparatem złożonym, opartym o sprawdzony i dobrze tolerowany inhibitor ACE, co jest ułatwieniem dla lekarza i wygodą dla pacjenta [36]. 


\section{Piśmiennictwo}

1. Chobanian A.V., Bakris G.L., Black H.R. i wsp. Seventh Report of the Joint National Committee on Prevention, Detection, Evaluation, and Treatment of High Blood Pressure. JAMA 2003; 289: 2560-2572.

2. Lewington $S$. i wsp. Age specific relevance of usual blood pressure to vascular mortality. A meta-analysis of individual data for one million adults in 61 prospective studies. Lancet 2002; 360: 1903-1913.

3. Wolf-Maier K., Cooper R.S., Banegas J.R. i wsp. Hypertension prevalence and blood pressure levels in 6 European Countries, Canada, and the United States. JAMA 2003; 289: 2363-2369.

4. Yoon S.S., Gu Q., Nwankwo T. i wsp. Trends in blood pressure among adults with hypertension United States, 2003 to 2012. Hypertension 2015; 65: 54-61.

5. Zdrojewski T., Wyrzykowski B., Szczęch R. i wsp. Epidemiology and prevention of arterial hypertension in Poland. Blood Press. 2005; 14 (supl. 2): 10-16.

6. Tykarski A., Posadzy-Małaczyńska A., Wyrzykowski B. i wsp. Rozpowszechnienie nadciśnienia tętniczego oraz skuteczność jego leczenia u dorosłych mieszkańców naszego kraju. Wyniki programu WOBASZ. Kardiol. Pol. 2005; 63: S614-S619.

7. Drukteinis J.S., Roman M.J., Fabsitz R.R. i wsp. Cardiac and systemic hemodynamic characteristics of hypertension and prehypertension in adolescents and young adults: the Strong Heart Study. Circulation 2007; 115: 221-227.

8. Franklin S.S., Gustin W., Wong N.D. i wsp. Haemodynamic Patterns of Age-Related changes in Blood Pressure. The Framingham Study. Circulation 1997; 96: 308-315.

9. Rajdeep S.K., Swales J.D., Dore K. i wsp. Effect of aging on the prognostic significance of ambulatory systolic, diastolic, and pulse pressure in essential hypertension. Circulation 2001; 104: 783-789.

10. McEniery C.M., Yasmin, Wallace S. i wsp. Increased stroke volume and aortic stiffness contribute to isolated systolic hypertension in young adults. Hypertension 2005; 46: 221-226.

11. McMahon C.A., Gidding S.S., Viikari J.S. i wsp. Association of Pathobiologic Determinants of Atherosclerosis in Youth risk score and 15-year change in risk score with carotid artery intima-media thickness in young adults (from the Cardovascular Risk in Young Finns Study). Am. J. Cardiol. 2007; 100: 1124-1129.

12. Pencina M.J., D’Agostino R.B., Sr. Larson M.G. i wsp. Predicting the 30-year risk of cardiovascular disease: the Framingham heart study. Circulation 2009; 119: 3078-3084.

13. Yambe M., Tomiyama H., Yamada J. i wsp. Arterial stiffness and progression to hypertension in Japanese male subjects with high normal blood pressure. J. Hypertens. 2007; 25: 87-93.

14. Saladini F., Dorigatti F., Santonastaso M. i wsp. Natural history of hypertension subtypes in young and middle-age adults. Am. J. Hypertens. 2009; 22: 531-537.

15. Tirosh A., Afek A., Rudich A. i wsp. Progression of normotensive adolescent to hypertensive adult. A study of 26980 teenagers. Hypertension 2010; 56: 203-209.

16. Anderson E.A., Sinkey C.A., Lawton W.J. i wsp. Elevated sympathetic nerve activity in borderline hypertensive humans. Evidence from direct intraneural recordings. Hypertension 1989; 14: 177-183.

17. Barker D.J., Osmond C., Golding J. i wsp. Growth in utero, blood pressure in childhood and adult life, and mortality from cardiovascular disease. BJM 1989; 298: 564-567.

18. Brenner B.M., Anderson S. The interrelationships among filtration surface area, blood pressure, and chronic renal disease. J. Cardiovasc. Pharmacol. 1992; 19 (supl. 6): S1-S7.

19. Law C.M., Shiell A.W., Newsome C.A. i wsp. Fetal, infant, and childhood growth and adult blood pressure: a longitudinal study from birth to 22 years of age. Circulation 2002; 105: 1088-1092.

20. Shear C.L., Burke G.L., Freedman D.S. i wsp. Value of childhood blood pressure managements and family history in predicting future blood pressure measurements and family history in predicting future blood pressure status: results from 8 years of follow-up in the Bogalusa Heart Study. Pediatrics 1986; 77: 862-869.

21. Schieken R.M. Genetic factors that predispose the child to develop hypertension. Pediatr. Clin. North. Am. 1993; 40: 1-11.
22. Carroll D., Ring C., Hunt K. i wsp. Blood pressure reactions to stress and the prediction of future blood pressure: effects of sex, age and socioeconomic position. Psychosom. Med. 2003; 65: 1058-1064.

23. Luque-Ramírez M., Alvarez-Blasco F., Mendieta-Azcona C. i wsp. Obesity is the major determinant of the abnormalities in blood pressure found in young women with the polycystic ovary syndrome. J. Clin. Endocrinol. Metab. 2007; 92: 2141-2148.

24. Ferreira I., Boreham C.A., Twisk J.W. i wsp. Clustering of metabolic syndrome risk factors and arterial stiffness in young adults: the Northern Ireland Young Hearts Project. J. Hypertens. 2007; 25: 1009-1020.

25. Tzou W.S., Douglas P.S., Srinivasan S.R. i wsp. Increased subclinical atherosclerosis in young adults with metabolic syndrome. The Bogalusa Heart Study. J. Am. Coll. Cardiol. 2005; 46: 457-463.

26. Lambert E., Sari C.I., Dawood T. i wsp. Sympathetic nervous system activity is associated with obesity-induced subclinical organ damage in young adults. Hypertension 2010; 56: 351-358.

27. Palatini P., Majahalme S., Amerena J. i wsp. Determinants of left ventricular structure and mass in young subjects with sympathetic over-activity. The Tecumseh Offspring Study. J. Hypertens. 2000; 18: 769-775.

28. Dimsdale J.E. Psychological stress and cardiovascular disease. J. Am. Coll. Cardiol. 2008; 51: 1237-1246.

29. Chandola T., Brunner E., Marmot M. Chronic stress at work and the metabolic syndrome: prospective study. Br. Med. J. 2006; 332: 521-525.

30. Tirosh A., Afek A., Rudich A. i wsp. Progression of normotensive adolescent to hypertensive adult. A study of 26980 teenagers. Hypertension 2010; 56: 203-209.

31. Lloyd-Jones D.M. Cardiovascular risk prediction: basic concepts, current status and future directions. Circulation 2010; 121: 1768-1777.

32. Matthews K.A., Katholi C.R., McCreath H. i wsp. Blood pressure reactivity to psychological stress predicts hypertension in the CARDIA study. Circulation 2004; 110: 74-78.

33. Harshfield G.A., Dong Y., Kapuku G.K. i wsp. Stress- induced sodium retention and hypertension: a review and hypothesis. Curr. Hypertens. Rep. 2009; 11: 29-34.

34. Laragh J.H. Vasoconstriction-volume analysis for understanding and treating hypertension. Am. J. Med. 1973; 55: 261-274.

35. Laragh J.H., Sealey J.E. Relevance of the plasma renin hormonal control system that regulates blood pressure and sodium balance for correctly treating hypertension and for evaluating ALLHAT. Am. J. Hypertens. 2003; 16: 407-415.

36. Tykarski A., Narkiewicz K., Gaciong Z. i wsp. Zasady postępowania w nadciśnieniu tętniczym - 2015 rok. Wytyczne Polskiego Towarzystwa Nadciśnienia Tętniczego. Nadciśnienie Tętnicze w Praktyce 2015; 1: 1-70.

37. Wytyczne ESH/ESC dotyczące postępowania w nadciśnieniu tętniczym w 2013 roku. Nadciśnienie Tettnicze 2013; 17: 69-168.

38. Urbina E., Alpert B., Flynn J. i wsp. Ambulatory blood pressure ambulatory blood pressure monitoring in children. Recommendations of standard assessment. A scientific statement from American Heart Association Atherosclerosis, Hypertension and Obesity in Youth Committee of the Council on Cardiovascular Disease in the Young and the Council for High Blood Pressure Research. Hypertension 2008; 52: 433-451.

39. Ben-Dov I.Z., Ben-Arie L., Mekler J. i wsp. Reproducibility of whitecoat and masked hypertension in ambulatory BP monitoring. Int. J. Cardiol. 2007; 117: 355-359.

40. Mahmud A., Feely J. Spurious systolic hypertension of youth: fit young men with elastic arteries. Am. J. Hypertens. 2003; 16: 229-232.

41. McEniery C.M., Yasmin, Wallace S. i wsp. Increased stroke volume and aortic stiffness contribute to isolated systolic hypertension in young adults. Hypertension 2005; 46: 221-226.

42. Falkner B., Gidding S.S., Portman R. i wsp. Blood pressure variability and classification of prehypertension and hypertension in adolescence. Pediatrics 2008; 122: 238-242.

43. Ben-Dov I.Z., Ben-Arie L., Mekler J. i wsp. In clinical practice, masked hypertension is as common as isolated clinic hypertension: predominance of younger men. Am. J. Hypertens. 2005; 18: 589-593. 
44. Vasan R.S. A risk score for risk factors: rationale and roadmap for preventing hypertension. Hypertension 2009; 54: 454-456.

45. Naess H., Nyland H.I., Thomassen L. i wsp. Etiology of risk factors for cerebral infarction in young adults in western Norway: a population-based case-control study. Eur. J. Neurol. 2005; 11: 25-30.

46. Julius S., Kaciroti N., Egan B.M. i wsp. Trophy Study: Outcomes based on the Seventh Report of the Joint National Committee on Hypertension definition of hypertension. J. Am. Soc. Hypertens. 2008; 2: 39-43.

47. Lurbe E., Cifkova R., Cruickshank J.K. i wsp. Management of high blood pressure in children and adolescents: recommendations of the European Society of Hypertension. J. Hypertens. 2009; 27: 1719-1742.

48. Blood Pressure Lowering Treatment Trialists' Collaboration: Effects of different regimes to lower blood pressure on major cardiovascular events in older and younger adults: meta-analysis of randomised trials. BMJ 2008; 336: 1121-1123.

49. Materson B.J., Reda D.J., Cushman W.C. i wsp. Single-drug therapy for hypertension in men. A comparison of six antihypertensive agents with placebo. The Department of Veterans Affairs Cooperative Study Group on Antihypertensive Agents. N. Engl. J. Med. 1993; 328: 914-921.

50. Savarese G., Costanzo P., Cleland J.G. i wsp. A meta-analysis reporting effects of angiotensin-converting enzyme inhibitors and angiotensin receptor blockers in patients without heart failure. J. Am. Coll. Cardiol. 2013; 61: 131-142.

51. Tsoukas G., Anand S., Yang K. For the CONFIDENCE Investigators. Dose-dependent antihypertensive efficacy and tolerability of perindopril in a large, observational, 12-week, general practice-based study. Am. J. Cardiovasc. Drugs 2011; 11: 45-55.

52. Tumanan-Mendoza B.A., Dans A.L., Villacin L.L. i wsp. Dechallenge and rechallenge method showed different incidences of cough among four ACE-Is. J. Clin. Epidemiol. 2007; 60: 547-553.

53. Ceconi C., Fox K.M., Remme W.J. i wsp. ACE inhibition with perindopril and endothelial function. Results of a substudy of the EUROPA study: PERTINENT. Cardiovascular. Research. 2007; 73: 237-246.

54. Bangalore S., Kumar S., Messerli F. Angiotensin-Converting Enzyme inhibitor associated cough: deceptive information from the physicians` desk reference. Am. J. Med. 2010; 123: 1016-1030.

55. Burchardt M., Burchardt T., Baer L i wsp. Hypertension is associated with severe erectile dysfunction. J. Urol. 2000; 164: 1188-1191.

56. Grimm R.H. Jr., Grandits G.A., Prineas R.J. i wsp. Longterm effects on sexual function of five antihypertensive drugs and nutritional hygienic treatment in hypertensive men and women: treatment of mild hypertension study (TOMHS). Hypertension 1997; 29: 8-14.

57. Leenen F.H., Wilson T.W., Bolli P. i wsp. Patterns of compliance with once versus twice daily antihypertensive drug therapy in primary care: a randomized clinical trial using electronic monitoring. Can. J. Cardiol. 1997; 13: 914-920.

58. Myers M.G. Trough-to-peak ratio and 24-hour blood pressure control. Am. J. Hypertens. 1995; 8: 214-219.
59. Omboni S., Parati G., Zanchetti A., Mancia G. Calculation of trough:peak ratio of antihypertensive treatment from ambulatory blood pressure: methodologic aspects. J. Hypertens. 1995; 18: 1105-1112.

60. Myers M.G. Suggested guidelines for determining the trough-to-peak ratio of antihypertensive drugs. Am. J. Hypertens. 1996; 9: 76S-82S.

61. Kuwajima I., Mitani K., Miyao M. i wsp. Cardiac implications of the morning surge in blood pressure in elderly hypertensive patients: relation to arising time. Am. J. Hypertens. 1995; 8: 29-33.

62. Marfella R., Gualdiero P., Siniscalchi M. i wsp. Morning blood pressure peak, QT intervals, and sympathetic activity in hypertensive patients. Hypertension 2003; 41: 237-243.

63. Kaplan N.M. Morning surge in blood pressure. Circulation 2003; 107: 1347.

64. Manfredini R., Gallerani M., Portaluppi F. i wsp. Chronobiological patterns of onset of acute cerebrovascular diseases. Thromb. Res. 1997; 88: 451-463.

65. Ghiadoni L., Magagna A., Versari D. i wsp. Different effect of antihypertensive drugs on conduit artery endothelial function. Hypertension 2003; 41: 1-6.

66. Fox K.M. EURopean trial ON reduction of cardiac events with Perindopril in stable coronary Artery disease Investigators. Efficacy of perindopril in reduction of cardiovascular events among patients with stable coronary artery disease: randomized, double-blind, placebo-controlled, multicenter trial (the EUROPA study). Lancet 2003; 362: 782-788.

67. Rodriguez-Granillo G.A., Vos J., Bruining N. i wsp. Investigarors of the EUROPA Study. Long-term effect of perindopril on coronary atherosclerosis progression (from the perindopril`s prospective effect on coronary atherosclerosis by angiography and intravascular ultrasound evaluation [PERSPECTIVE] study). Am. J. Cardiol. 2007; 100: 159-163.

68. Ruzicka M., Leenen F.H. Combination therapy as first line treatment of arterial hypertension. Can. J Cardiol. 2002; 18: 1317-1327.

69. Dahlof B. i wsp. Ascot Investigators: Prevention of cardiovascular events with an antihypertensive regimen of amlodipine adding perindopril as required versus atenolol adding bendroflumethiazide as required in the Anglo-Scandinavian Cardiac Outcomes Trial-Blood Pressure Lowering Arm (ASCOT-BLA): a multicentre randomised controlled trial. Lancet 2005; 366: 895-906.

70. PROGRESS Collaborative Group: randomised trial of a perindopril-based blood-pressure-lowering regiment among 6105 individuals with previous stroke or transient ischemic attack. Lancet 2001; 358: 1033-1041.

71. Chalmers J., Arima H., Woodward M i wsp. Effects of combination of perindopril, indapamide, and calcium channel blockers in patients with type 2 diabetes mellitus results from the Action in Diabetes and Vascular Disease: Preterax and Diamicron Controlled Evaluation (ADVANCE) trial. Hypertension 2014; 63: 259-264.

72. Van Vark L.C., Bertrand M., Akkerhuis K.M. i wsp. Angiotensin-converting enzyme inhibitors reduce mortality in hypertension: a metaanalysis of randomized clinical trials of renin-angiotensin-aldosterone system inhibitors involving 158998 patients. Eur. Heart J. 2012; 33: 2088-2097. 